\title{
The Impact of Psychotropic Drugs on Psychosocial Functioning in Bipolar Disorder
}

\author{
Omer Aydemir', Pinar Cetinay Aydin², Demet Gulec Oyeckin³, Seref Gulseren ${ }^{4}$, \\ Gulperi Putgul Koybasi ${ }^{5}$, Hasan Sahin ${ }^{6}$
}

ÖZET:

İki uçlu bozuklukta kullanılan ilaçların psikososyal işlevsellik üzerine etkisi

\begin{abstract}
Amaç: iki uçlu bozuklukta hastalar düzelmiş olsalar bile psikososyal işlevsellik tam olarak kazanılamamaktadır. Kalıntı depresyon belirtileri, geçirilen dönem sayısı gibi klinik etkenler neden olmaktadır. Hastaların kullandığı ilaç tedavilerinin nasıl bir etki oluşturduğu yeterince araştııı tedavisi modalitelerinin düzelmiş iki uçlu bozukluk hastalarında psikososyal işlevsellik üzerine etkisini belirlemektir.
\end{abstract}

Yöntem: Araştırma iki uçlu bozukluk tanısı konmuş 108 hasta ile yürütülmüştür. Tüm hastalar düzelmiştir ve düzelme durumları ölçeklerle belirlenmiştir. Hastalarda işlevselliğin değerlendirilmesinde Kısa İşlevsellik Değerlendirme Ölçeği uygulanmıştır ve özerklik, mesleki işlevsellik, bilişsel işlevsellik, mali konular, kişiler arası ilişkiler ve boşzaman etkinlikleri boyutlarını içermektedir. Hastaların kullandıkları ilaç tedavisi modaliteleri duygudurum dengeleyici (DDD) ve duygudurum dengeleyici ve ikinci kuşak antipsikotik ilaçların birlikte (DDD+IKA) kullanıımasından oluşmaktadır. İstatistiksel analizde, çoklu regresyon analizi kullanıımıştır.

Bulgular: Hastaların \%38 ( $\mathrm{s}=41)^{\prime} \mathrm{i}$ tedavide sadece duygudurum dengeleyici kullanırken, geri kalan 67 hasta (\%62) duygudurum dengeleyiciye ek olarak ikinci kuşak antipsikotik kullanmaktadır. Çoklu regresyon analizinde, psikososyal işlevsellik ile ilgili boyutların her biri için kurulan modelde özerklik, kişilerarası ilişkiler ve boş zaman etkinlikleri boyutunun yer aldığı modeller istatistiksel olarak anlamlı bulunmuştur ve HAM-D puanı ile DDD+IKA kullanılması bu boyutları olumsuz etkilemiştir.

Sonuç: Kalıntı depresyon belirtilerinin yanı sıra tedavide bulundurulan ikinci kuşak antipsikotik ilaçların psikososyal işlevsellik üzerine olumsuz etkisi bulunmaktadır.

Anahtar sözcükler: İki uçlu bozukluk, psikososyal işlevsellik, duygudurum dengeleyicileri, ikinci kuşak antipsikotikler

Klinik Psikofarmakoloji Bulteni 2014;24(2):122-7

\section{ABSTRACT:}

The impact of psychotropic drugs on psychosocial functioning in bipolar disorder

Objective: Even though bipolar patients achieve remission, they do not reach premorbid psychosocial functioning. Factors such as residual depressive symptoms and number of episodes may cause this effect. The impact of treatment modalities has not been adequately studied. The aim of this study was to evaluate the impact of treatment modalities on psychosocial functioning in remitted bipolar patients.

Methods: The study was carried out with 108 patients diagnosed as having bipolar disorder. All patients were in remission and the remission state was confirmed by rating scales. In the assessment of functioning, the Functioning Assessment Short Test (FAST) covering domains such as autonomy, occupational functioning, cognitive functioning, financial issues, interpersonal relations, and leisure time activities was applied. The treatment modalities were mood stabilizers (MS) versus mood stabilizers plus second-generation antipsychotics (MS+SGA). While $38 \%(n=41)$ of the patients were on MS only, 67 patients (62\%) were on MS+SGA. In the statistical analysis, multiple linear regression analysis was performed.

Results: In multiple linear regression analyses, the models concerning autonomy, interpersonal relations, and leisure time were statistically significant. In patients on MS+SGA, autonomy (Beta $=3.086, p<0.01$ ), interpersonal relations (Beta $=2.807, p<0.01$ ) and leisure time activities (Beta=3.293, $p<0.01$ ) were affected negatively. Similarly, total HAM-D score had negative effects on the same domains.

Conclusion: Beside residual depressive symptoms, second-generation antipsychotics used in the treatment seem to affect psychosocial functioning negatively.

Keywords: bipolar disorder, psychosocial functioning mood stabilizers, second-generation antipsychotics

Bulletin of Clinical Psychopharmacology 2014;24(2):122-7
'Prof., Celal Bayar University, School of Medicine, Department of Psychiatry, Manisa - Turkey

${ }^{2}$ M.D., Bakirkoy Mazhar Osman Research and Training Hospital for Mental and Neurological Diseases, Istanbul - Turkey ${ }^{3}$ Assoc. Prof., Canakkale Onsekiz Mart University, School of Medicine Department of Psychiatry, Canakkale - Turkey ${ }^{4}$ M.D., Izmir Ataturk Research and Training Hospital, Psychiatry Clinic, Izmir - Turkey

${ }^{5}$ M.D., Menemen State Hospital, Psychiatry Clinic, Izmir - Turkey ${ }^{6}$ M.D., Kemalpasa State Hospital, Psychiatry Clinic, Bursa - Turkey

Address reprint requests to: Dr. Omer Aydemir Celal Bayar Üniversitesi, Psikiyatri Anabilim Dalı, Manisa - Türkiye

E-mail address:

soaydemir@yahoo.com

Date of submission: October 11, 2013

Date of acceptance: January 23, 2014

Declaration of interest:

O.A., P.C.A., D.G.O., S.G., G.P.K., H.S.: The authors reported no conflict of interest related to this article. 


\section{INTRODUCTION}

Even though bipolar disorder is a mental disorder with a course of episodes where patients are suggested to recover between episodes, it has been shown that they do not recover completely during remission ${ }^{1}$ and they do not achieve premorbid functioning ${ }^{2}$. Both occupational and social functioning of the patients do not revert to premorbid levels and while their productivity decreases, their well-being is impaired markedly ${ }^{4}$. There are various factors affecting the functionality of patients during remission. Among these, residual or sub-syndromal depressive symptoms are the most studied and suggested to be the cause. It has been demonstrated that residual depressive symptoms have impacts on social, occupational and cognitive functioning ${ }^{5-7}$. In addition, comorbid conditions such as anxiety disorders, medical conditions or diseases and pharmacological treatment for such conditions may have effects on functioning.

It is widely known that bipolar patients are on intensive drug treatment during the course of their illness ${ }^{8}$. The number and variety of psychotropic drugs are increased during manic episodes ${ }^{9}$ and most of the drugs are prescribed for a long time. On the other hand, second-generation antipsychotics have an important role in the treatment of bipolar disorder and they are used either as combination therapy or as an alternative treatment to mood stabilizers in routine daily practice ${ }^{10}$. The impact of drug treatment on the impairment of psychosocial functioning in bipolar patients is not well studied. In a study by Yen et al. ${ }^{11}$, it has been suggested that use of second-generation antipsychotics do not have any effect on quality of life, but there are some differences among the drugs themselves. However, it has been indirectly shown that the number of psychotropic drugs had a negative impact on quality of life of bipolar patients ${ }^{3}$. As a result, it has not been determined, how this effect is caused and how it is related to daily life.

In this study, the aim was to determine the effect of psychotropic drug treatment on psychosocial functioning in bipolar patients during remission.
With this purpose, beside the factors, which have been shown previously to have effects on psychosocial functioning, a model was used which also takes into consideration pharmacological treatment modalities.

\section{METHOD}

This study was carried out with bipolar patients attending the Mood Disorder Unit of Celal Bayar University, Department of Psychiatry, the Outpatient Department of Psychiatry of Izmir Atatürk Training and Research Hospital, and the Department of Psychiatry of Erzincan State Hospital.

\section{Study Sample}

The study is carried out with remitted bipolar patients. Inclusion criteria were being older than 18 years, fulfilling the diagnosis bipolar disorder type I or II according to DSM-IV criteria, and having the cognitive ability to comply with study procedure. The diagnostic assessment of the patients was made by the psychiatry specialists who are the authors of the study. Exclusion criteria were having any psychiatric disorder including any alcohol or substance misuse other than bipolar disorder type I or II, and having any neurological or organic diagnosis requiring permanent treatment. Only patients in remission were included to the study. The remission state was confirmed by a 17 -item Hamilton Depression Rating Scale (HAM-D) score less than 7 and a Young Mania Rating Scale (YMRS) score less than 4 at the time of the SCID-CV interview. One hundred and forty-seven patients were screened for the study, but only 108 patients, who were in remission were included.

The study was approved by the Local Ethical Committee of Celal Bayar University.

\section{Study Instruments}

For assessing mood symptoms, the Young Mania Rating Scale (YMRS) ${ }^{12}$ and the 17 -item Hamilton Depression Rating Scale (HAM-D) ${ }^{13}$ were used. 
For assessing the level of psychosocial functioning of the patients, the Functional Assessment Short Test (FAST) was used. The FAST was developed by Rosa et al. ${ }^{14}$ and the validation study for Turkish was performed by Aydemir and Uykur $^{15}$. It is a 24 -item self-rated scale with 4-point Likert type rating, and it has six domains: autonomy, occupational functioning, cognitive functioning, financial issues, interpersonal relations, and leisure time activities. A higher score means worse functioning. The FAST does not have a cut-off point; and even though it has domains, the total score is used in the analysis.

\section{Statistical Analysis}

To evaluate the impact of pharmacological treatment modalities on psychosocial functioning, a stepwise regression model was established. The model was tested with multiple linear regression analyses. The patients were separated into two groups, patients, who were only on mood stabilizers (MS) and patients who were on mood stabilizers combined with a second-generation antipsychotic (MS+SGA), and the model was tested on these two groups. In this model, in addition to the pharmacological treatment modality for every domain of functioning, mood symptoms such as depression and mania, duration of the disease and number of mood episodes were also taken into account. Accordingly, in the first step total scores of the HAM-D and YMRS, in the second step duration of the disease and number of mood episodes and in the third step pharmacological treatment modalities wereincluded in the regression model. Monotherapy versus combination therapy was considered as a dummy variable and combination therapy (MS+SGA) was coded as 1 . This model was repeated for every domain of psychosocial functioning in the analysis.

\section{RESULTS}

In the study 108 volunteers were included and the mean age was $39.1 \pm 11.6$ years; female patients were $57.4 \%(n=62)$ of the group. Nearly all of the
Table 1: Demographic and clinical features of the study group.

\begin{tabular}{|c|c|c|}
\hline & \multicolumn{2}{|c|}{$\begin{array}{c}\text { Bipolar disorder } \\
\qquad n=108\end{array}$} \\
\hline Age (years) & \multicolumn{2}{|c|}{$39.1 \pm 11.6$} \\
\hline \multicolumn{3}{|l|}{ Gender } \\
\hline Male & 46 & $42.6 \%$ \\
\hline Female & 62 & $57.4 \%$ \\
\hline \multicolumn{3}{|l|}{ Education } \\
\hline Primary & 65 & $60.2 \%$ \\
\hline High school & 23 & $21.3 \%$ \\
\hline University & 20 & $18.5 \%$ \\
\hline \multicolumn{3}{|l|}{ Bipolar type } \\
\hline Bipolar disorder type I & 100 & $92.6 \%$ \\
\hline Bipolar disorder type I & 8 & $7.4 \%$ \\
\hline Duration of disease (years) & \multicolumn{2}{|c|}{$11.8 \pm 8.4$} \\
\hline Number of episodes & \multicolumn{2}{|c|}{$19.6 \pm 31.0$} \\
\hline HAM-D & \multicolumn{2}{|c|}{$2.1 \pm 2.4$} \\
\hline YMRS & \multicolumn{2}{|c|}{$0.7 \pm 1.5$} \\
\hline
\end{tabular}

Table 2: Distribution of psychotropic drugs ( $n=108)$.

\begin{tabular}{lcc} 
Drugs & Number & \% \\
\hline Lithium & 24 & 22.2 \\
Valproate & 10 & 9.2 \\
Lithium+Valproate & 8 & 7.4 \\
Lithium+Olanzapine & 6 & 5.5 \\
Lithium+Quetiapine & 14 & 12.9 \\
Lithium+Aripiprazole & 2 & 1.8 \\
Lithium+Risperidone & 3 & 2.7 \\
Valproate+Olanzapine & 5 & 4.6 \\
Valproate+Quetiapine & 20 & 18.5 \\
Valproate+Aripiprazole & 2 & 1.8 \\
Valproate+Risperidone & 4 & 3.7 \\
Lithium+Valproate+Quetiapine & 3 & 2.7 \\
\hline
\end{tabular}

patients $(92.6 \%)$ were diagnosed as bipolar disorder type I. The duration of the disease was $11.8 \pm 8.4$ years, and mean number of previous mood episodes was 19.6 \pm 31.0 . Demographic and clinical features of the patients are shown in Table 1 . While $38 \%(n=41)$ of the patients were on only mood stabilizers, 67 patients $(62 \%)$ were on mood stabilizers combined with second-generation antipsychotics. Pharmacological drug treatment of the patients is shown in Table 2.

In the multiple linear regression analysis where a model for each domain of psychosocial functioning was tested, autonomy, interpersonal relations, and 
Table 3: Multiple linear regression table associated with treatment modality and Functioning Assessment Short Test. The analysis was performed stepwise and in the first step mood symptoms are included, in the second step clinical variables are added, and in the third step treatment modality variable was added.

\begin{tabular}{|c|c|c|c|c|c|c|}
\hline Variables & AUT & OCC & COG & FIN & IPR & LTA \\
\hline Constant (B) & -0.219 & 0.837 & 2.020 & 0.134 & 0.505 & 7.687 \\
\hline \multicolumn{7}{|c|}{ First step: including mood symptoms in the analysis } \\
\hline HAM-D & $2.186^{\mathrm{b}}$ & 1.178 & 1.398 & 0.525 & $2.753^{a}$ & $3.396^{\mathrm{a}}$ \\
\hline YMRS & 0.540 & -1.222 & -1.277 & -0.133 & -0.348 & -0.908 \\
\hline \multicolumn{7}{|c|}{ Second step: including clinical variables in the analysis } \\
\hline Duration of disease & -0.123 & 0.090 & -0.249 & -0.924 & 0.044 & -0.077 \\
\hline Number of episodes & -0.531 & -0.381 & -1.276 & 0.402 & -0.500 & -1.195 \\
\hline \multicolumn{7}{|c|}{ Third step: including treatment modalities in the analysis } \\
\hline$M S+S G A$ & $3.086^{\mathrm{a}}$ & 2.213 & 1.152 & 0.657 & $2.807^{\mathrm{a}}$ & $3.293^{\mathrm{a}}$ \\
\hline $\mathrm{R} 2$ & 0.146 & 0.145 & 0.052 & 0.037 & 0.158 & 0.201 \\
\hline Corrected R2 & 0.092 & 0.023 & -0.008 & -0.024 & 0.098 & 0.151 \\
\hline Standard error & 2.164 & 3.990 & 2.945 & 1.405 & 3.503 & 1.409 \\
\hline $\mathrm{F}$ & 2.702 & 1.190 & 0.872 & 0.611 & 2.605 & 3.982 \\
\hline$P$ & 0.018 & 0.330 & 0.519 & 0.721 & 0.023 & 0.001 \\
\hline
\end{tabular}

leisure time activities were found to be statistically significant (Table 3). In the analysis of autonomy, $\mathrm{R}$ square was calculated to be 0.146 , and the model is statistically significant $(\mathrm{F}=2.702, \mathrm{p}=0.018)$. MS+SGA treatment (Beta=3.086, $\mathrm{p}<0.01$ ) and HAM-D score $($ Beta $=2.186, \mathrm{p}<0.05)$ had an effect on this domain. In the model for interpersonal relations, $\mathrm{R}$ square was found to be 0.158 , and F coefficient was 2.605 $(\mathrm{p}=0.023)$. HAM-D score $($ Beta $=2.753, \mathrm{p}<0.01)$ and MS+SGA (Beta $=2.807, \mathrm{p}<0.01)$ had an effect on the interpersonal relations domain. In the analysis for leisure time activities, $\mathrm{R}$ square was calculated to be 0.201 , and the model was statistically significant $(\mathrm{F}=3.982, \mathrm{p}=0.001)$. MS+SGA treatment $(\mathrm{Beta}=3.293$, $\mathrm{p}<0.01)$ and HAM-D score $($ Beta $=3.396, \mathrm{p}<0.05)$ had an effect on this domain.

Models for domains of occupational functioning, cognitive functioning, and financial issues did not yield statistically significant results.

\section{DISCUSSION}

In this study, psychosocial functioning of remitted bipolar patients was evaluated and the effect of pharmacological treatment was determined. Like in previous studies ${ }^{16}$, while it has been shown that the effect of depressive symptoms have an impact on psychosocial functioning, it was also demonstrated that in patients with a treatment combining mood stabilizer and second-generation antipsychotic, domains of psychosocial functioning such as autonomy, interpersonal relations and leisure time activities were negatively affected. This study is the first study to assess directly the impact of pharmacological treatment on psychosocial functioning.

It has been previously demonstrated that pharmacological treatment in bipolar disorder, especially second-generation antipsychotics were shown to have negative effect on cognitive functions ${ }^{17}$. On the other hand, especially in schizophrenic patients, it was suggested that second-generation antipsychotics had a better effect on psychosocial functioning and quality of life, compared to classical antipsychotics ${ }^{18}$, but when the severe impairment of schizophrenic patients is taken into consideration, it is not expected that they would achieve their premorbid level of functioning ${ }^{19}$. In a study on lithium treatment in bipolar disorder, it has been suggested 
that the treatment improved the quality of life of the patients by preventing the recurrence of mood episodes $^{20}$.

In studies on psychosocial functioning and quality of life in bipolar disorder, number of psychotropic drugs and adverse effects of pharmacological treatment have been found to affect functioning negatively ${ }^{3}$. In another study based on a classification taking into account global functioning score and occupational status, bipolar patients were classified into two classes regarding their pharmacological treatment as having good or poor functions, and lithium and valproate are found to be statistically significant in the good functioning group $^{21}$. Yen et al. ${ }^{11}$ evaluated quality of life in patients with bipolar disorder compared both with patients with schizophrenia and healthy control subjects, and studied the effect of second-generation antipsychotics. Quality of life of bipolar patients was similar to that of patients with schizophrenia and worse than that of healthy control subjects, and it was suggested that pharmacological treatment does not have any effect. In addition, patients who experience adverse events have worse quality of life than patients who have never used psychotropic drugs. As a result, use of second-generation antipsychotics affects quality of life negatively. In this present study, it has been demonstrated that combination therapy has negative effect on the domains of psychosocial functioning such as autonomy, interpersonal relations and leisure time activities

In previous studies, it has been reported that patients with a difficult-to-treat disorder, with more residual symptoms and with a more frequently recurrent course of disease require more drugs in treatment ${ }^{8}$. Since the psychopathology of these patients is already more severe, it is expected that they have poor functioning. On the other hand, in bipolar patients, second-generation antipsychotics cause more adverse effects, and patients have difficulties in adapting to their treatment ${ }^{22}$. It should be considered that adverse effects have a significant effect on functioning and quality of life ${ }^{3}$. As a result, beside residual depressive symptoms, in bipolar patients second-generation antipsychotics also reduce participation in leisure time activities, cause avoidance of interpersonal relations, and reduce initiative by affecting autonomy.

\section{Advantages and limitations of the study}

This study is a cross-sectional study and since it does not cover the follow-up period, it may be inadequate to demonstrate longitudinal effects of symptoms and therapies. Thus, longitudinal studies are needed to generalize the results. Since the study is cross-sectional, bipolar patients, who are only on mood stabilizers may have a disease with a more favorable course or less severe episodes when compared with patients who are on mood stabilizers combined with second-generation antipsychotics. Therefore when reading the results of the study, it should be kept in mind that the difference in functioning may be caused by factors other than treatment modalities. The study was carried out in institutions with specialized mood disorder clinics, and at the same time in tertiary health care centers, therefore one should be cautious to generalize the results of this study. The advantages of this study are that is has an adequate sample size and that the subgroups have similar features.

\section{CONCLUSION}

Even though bipolar patients achieve remission, they do not return to their premorbid level of psychosocial functioning. Beside residual depressive symptoms, second-generation antipsychotics used in the treatment also have a negative impact. In the long-term follow-up of patients with bipolar disorder, psychotropic drugs should be reviewed, drugs that are not needed anymore should be tapered off, and cost benefit ratio of ongoing psychotropic drugs should be taken into account. 


\section{References:}

1. Kaya E, Aydemir O, Selcuki D. Residual symptoms in bipolar disorder: The effect of the last episode after remission. Prog Neuropsychopharmacol Biol Psychiatry 2007;31(7):1387-92. [CrossRef]

2. Rosa AR, Reinares M, Amann B, Popovic D, Franco C, Comes $\mathrm{M}$, et al. Six-month functional outcome of a bipolar disorder cohort in the context of a specialized-care program. Bipolar Disord 2011;13(7-8):679-86. [CrossRef]

3. Sanchez-Moreno J, Martinez-Aran A, Tabarés-Seisdedos R, Torrent C, Vieta E, Ayuso-Mateos JL. Functioning and disability in bipolar disorder: an extensive review. Psychother Psychosom 2009;78(5):285-97. [CrossRef]

4. Michalak EE, Yatham LN, Lam RW. Quality of life in bipolar disorder: a review of the literature. Health Qual Life Outcomes 2005;3:72. [CrossRef]

5. Ozer S, Ulusahin A, Batur S, Kabakci E, Saka MC. Outcome measures of interepisode bipolar patients in a Turkish sample. Soc Psychiatry Psychiatr Epidemiol 2002;37(1):31-7. [CrossRef]

6. Kaya E, Aydemir O, Selcuki D. The effects of residual affective symptoms on cognitive and social functioning in remitted bipolar patients. Anatolian Journal of Psychiatry 2009;10(2):124-30.

7. Bonnín CM, Sánchez-Moreno J, Martínez-Arán A, Solé B, Reinares M, Rosa AR, et al. Subthreshold symptoms in bipolar disorder: impact on neurocognition, quality of life and disability. J Affect Disord 2012;136(3):650-9. [CrossRef]

8. Post RM, Denicoff KD, Leverich GS, Altshuler LL, Frye MA, Suppes TM, et al. Morbidity in 258 bipolar outpatients followed for 1 year with daily prospective ratings on the NIMH life chart method. J Clin Psychiatry 2003;64(6):680-90. [CrossRef]

9. Yazici O, Aydemir O, Guloksuz S, Akdeniz F, Yenilmez C, Akkaya C, et al. Treatment of manic patients during hospitalization - a retrospective chart review in 2004-2008: what has changed? Presented at $22^{\text {nd }}$ ECNP Congress 12 - 16 September 2009, Istanbul.

10. Vacheron-Trystram MN, Braitman A, Cheref S, Auffray L. Antipsychotics in bipolar disorders. Encephale 2004;30(5):417-24. [CrossRef]

11. Yen C-F, Cheng C-P, Huang C-F, Yen J-Y, Ko C-H, Chen C-S. Quality of life and its association with insight, adverse effects of medication and use of atypical antipsychotics in patients with bipolar disorder and schizophrenia in remission. Bipolar Disord 2008;10(5):617-24. [CrossRef]
12. Karadag F, Oral T, Yalcin AF, Erten E. Reliability and Validity of Turkish Translation of Young Mania Rating Scale. Turk Psikiyatr Derg 2002;13(2):107-14.

13. Akdemir A, Orsel S, Dag I, Turkcapar H, Iscan N, Ozbay H. Validity, reliability and clinical use of Hamilton Depression Rating Scale. Psikiyatri Psikoloji Psikofarmakoloji Dergisi 1996;4(2):251-9.

14. Rosa AR, Sanchez-Moreno J, Martinez-Aran A, Salamero $\mathrm{M}$, Torrent $\mathrm{C}$, Reinares $\mathrm{M}$, et al. Validity and reliability of the Functioning Assessment Short Test (FAST) in bipolar disorder. Clinical Practice and Epidemiology in Mental Health 2007;3:5. [CrossRef]

15. Aydemir O, Uykur B. Reliability and validity study of the Turkish version of Functioning Assessment Short Test in bipolar disorder. Turk Psikiyatr Derg 2012;23(3):193-200.

16. Bonnín CM, Martínez-Arán A, Torrent C, Pacchiarotti I, Rosa AR, Franco C, et al. Clinical and neurocognitive predictors of functional outcome in bipolar euthymic patients: a longterm, follow-up study. J Affect Disord 2010;121(1-2):156-60. [CrossRef]

17. Torrent C, Martinez-Arán A, Daban C, Amann B, BalanzáMartínez V, del Mar Bonnín C, et al. Effects of atypical antipsychotics on neurocognition in euthymic bipolar patients. Compr Psychiatry 2011;52(6):613-22. [CrossRef]

18. Awad AG, Voruganti LN. Impact of atypical antipsychotics on quality of life in patients with schizophrenia. CNS Drugs 2004;18(13):877-93. [CrossRef]

19. Ritsner M, Gibel A, Perelroyzen G, Kurs R, Jabarin M, Ratner Y. Quality of life outcomes of risperidone, olanzapine, and typical antipsychotics among schizophrenia patients treated in routine clinical practice: a naturalistic comparative study. J Clin Psychopharmacol 2004;24(6):582-91. [CrossRef]

20. Solomon DA, Ristow WR, Keller MB, Kane JM, Gelenberg AJ, Rosenbaum JF, et al. Serum lithium levels and psychosocial function in patients with bipolar I disorder. Am J Psychiatry 1996; 153(10):1301-7.

21. Martinez-Aran A, Vieta E, Torrent C, Sanchez-Moreno J, Goikolea JM, Salamero M, et al. Functional outcome in bipolar disorder: the role of clinical and cognitive factors. Bipolar Disord 2007;9(1-2):103-13. [CrossRef]

22. Chen W, Deveaugh-Geiss AM, Palmer L, Princic N, Chen YT. Patterns of atypical antipsychotic therapy use in adults with bipolar I disorder in the USA. Hum Psychopharmacol. 2013;28(5):428-37. [CrossRef] 